\title{
Professional Practice and Engineering Interns: THREe CASES FOR DISCUSSION
}

\author{
A Roncin, M.G. Britton, and G. Koropatnick \\ Red River College, University of Manitoba, Association of Professional Engineers and Geoscientists of Manitoba \\ aroncin@ rrc.ca, ron.britton@umanitoba.ca, gkoropatnick@apegm.mb.ca
}

\begin{abstract}
A key phrase in discipline findings of professional misconduct is "The engineer knew or ought to have known". By virtue of being members of the engineering profession, Engineers are expected to demonstrate both technical competence and professionalism. The three cases in this paper look at professionalism from the standpoint of trust from the perspective of the regulator, the client, and peers.

When that trust is broken, complaints against the engineer can ensue and unless the member has worked with the investigation committee or been investigated before, it is unlikely that they would know the disciplinary process and the scope within which they operate.

This paper is aimed at fostering classroom discussions about the ethical situations Engineering Interns could find themselves in and offers ideas on how the investigation/discipline process can be brought to the classroom.
\end{abstract}

Keywords: Engineering Ethics, Professional Practice, Case Studies

\section{INTRODUCTION}

High profile cases like the 2011 Charbonneau Commission [1][2] and 2012 Elliot Lake Inquiry [3] are touchstones that remind us that engineers are human, and pressures from organized crime, community leaders, and important clients can lead engineers to put aside their professional obligations in an effort to meet the challenges at hand. These high profile cases, are powerful and emotional touchstones of ethical failures in Canadian engineering, however there is much more to learning about the professional and ethical responsibilities of an engineer. Students need to be aware of the importance of trust and professionalism in their day to day activities with the regulator, their clients, and their peers.

Canada is a nation rich with engineering achievements. And unlike the United States or United Kingdom, engineering in Canada is a self governing professional discipline - a status based on the trust. The public (governments) trust that engineers will use their problem solving skills and specialized knowledge for the betterment of those we work with.

Yet like any other group, a few bad apples can spoil the bunch. And when that trust is broken, the provincial engineering regulatory bodies are left the mess of investigating and disciplining the members involved.

\section{IMPORTANCE OF ENGINEERING ETHICS}

Fortunately, most engineers act in an ethical and respectful manner and never become involved in the disciplinary process. Unfortunately, those same practicing engineers are often unaware of how the disciplinary process works. Unaware of the actions that often lead to an investigation, the powers of the discipline committee, and the scope within which they operate.

\subsection{Costs to the Profession}

When a complaint of unskilled practice or professional misconduct is brought against an engineer, it represents a loss of trust in the profession. Treating the matter fairly and being seen as treating the matter fairly, requires a significant amount of time, money, and resources on the part of the provincial association. A single investigation can take years to complete and cost tens of thousands of dollars.

\subsection{Costs to the Individual}

Regardless of guilt or innocence of the engineer involved, the investigation into an engineer's professional practice is both mentally and financially exhausting. Being under scrutiny and potentially losing your career can be invasive, stressful, and frightening. On top of that, there are also the financial costs of defence lawyers, court fees, and time away from the business.

\section{CASE STUDIES}

The number one canon for engineers in Canada is protection of the public. We decide how technology is 
going to be used, whose values will be considered, and what safety precautions will be built into the design.

Returning to the cases of Charbonneau and Elliot Lake, a deeper question here is, what do young engineers, working in those environments learn about professional ethics, and the engineering profession as a whole? Do they learn the importance of telling the truth? Are they mentored in good business practices like writing clear business agreements, detailed contracts, and concise recommendations? Do they understand that engineering is founded on trust, professionalism and cooperation?

Students need to see examples of both good behaviour and bad behaviour to be able to understand and contextualize what is expected of them.

The following three examples of professional ethics, are based on real events, and chosen because they represent decisions that students will likely face early in their career - decisions about honesty, communication, and transparency.

\subsection{Case 1: Registration}

Career stage -New graduates, applying for licensure, first-time applicants.

Code References - Manitoba Code of Ethics Canon 1.1, 1.3 [4].

Application - Telling the truth, good character, honour, integrity.

Engineering regulators across Canada have an application form which includes a section asking about character. Some are longer than others. Most ask the question: "Have you ever been convicted of a criminal offense? Yes or no? If yes, please provide details." According to the Engineers Geoscientists of Manitoba Registrar, most applicants respond with "no". However, as the Driving while Under the Influence of alcohol is more common than one might expect an increasing number of applicants are responding with "yes - DUI". It is a sign of the current conditions in Canadian society.

Graduates and those making application to an engineering regulator for the first time should take the question seriously. Don't lie or misrepresent the truth. Although it is reprehensible to drive while under the influence of alcohol, it is considered a worse offense to do it and lie about it. It's better to admit having been caught and to pledge never to do it again. The principle of committing a crime, doing the time and getting a second chance is one that is generally accepted by most people.

Telling the truth sounds so easy. Telling a lie or hiding the truth might also sound easy. Who's going to know? The Privacy Act limits the extent of inquiry an agency can make about a person, right. So how would they find out?
Consider the predicament of one applicant who answered "no" to the "criminal conviction question." The applicant had served a prison sentence for a crime committed about a decade earlier. This was disclosed in a reference letter sent to the regulator by a former employer. The applicant was denied a license for having lied about their personal history and failing to complete a series of steps to regain good character ordered by the regulator. Upon application to another regulator in a neighboring province, the cross-border checking done between regulators shared the information and the applicant was denied a second time.

Although we may not know why the applicant chose to deceive the regulator, it demonstrates behaviour unbecoming of an engineer and implies that the applicant will be dishonest with clients and the public in the future. The engineering profession is based on trust. And if we cannot trust an engineer when they register, when can we trust them? [5][6]

\subsection{Case 2: Documentation and Journaling}

Career stage - New graduates, first job experience, engineer-in-training.

Code References - Manitoba Code of Ethics Canon 3.1, 3.3 [4].

Application - Good business practices, liability and risk mitigation.

Young professionals beginning their careers should be mentored by older professionals on many aspects of professional practice including business practices. What if the mentor sets a poor example instead of a good one? According to Hollander and Arenberg [7, p. 30] mentoring focused professional survival rather than good research practices and personal assistance results in an increase in unethical behaviour.

A situation in which a junior engineer or engineering intern could easily find themselves in is attending client meetings to observe, take notes or provide other supports.

Consider the case of a lunch meeting with clients to discuss the early options for a design project. It may sound antiquated, but preliminary design sketches still get drawn on napkins, envelopes or daily newspapers. As a result, Investigation Committees still see evidence submitted by complainants of engineers who had sketched a design on a scrap of paper, verbally discussed the scope of work and confirmed the deal with a hand-shake.

Although this has the appearance of clarity, certainty and honour, a hasty sketch and hand-shake is not a recommended "best practice" for a junior engineer to emulate.

Rather, guidelines are available from regulators and industry groups describing service contracts and how they

CEEA17; Paper 027

University of Toronto; June 4-7, 2017 
are intended to be used [8][9]. Written descriptions of services, timelines, dollar amounts, definitions and legal disclaimers are standard sections in an agreement between engineer and client. Many complaints would never be lodged against a professional engineer if a written agreement was struck from the outset of a project. Young engineers and their mentors can avoid the liability risks associated with ambiguities caused by unwritten agreements, vague sketches and cost underestimates by always working from a carefully drafted service agreement.

\subsection{Case 3: Reviewing Engineering Work}

Career stage - Professional engineers at any career stage.

Code References - Manitoba Code of Ethics Canon 4.1, 5.6 [4].

Application - Communication between peers, good character, integrity, transparency.

To ensure cooperation, fairness and respect between professional engineers, it is necessary to properly notify another engineer when reviewing their work.

A typical complaint the Investigation Committee sees is cases where cooperation is not achieved and a complaint against a member is filed by another engineer or authority having jurisdiction.

As an example of best practices, consider the following situation: two engineers work on the same project but separated by a decade of time. Before making design changes, the new engineer contacts the original engineer to ask questions about the original design and understand how his decisions might affect the system. Although the proposed changes were vastly different from the original design, the first engineer cooperated and provided important notes and details which assisted in the changes. As a formal courtesy (and consistent with Canons 4.1 and 5.6 of the Manitoba Code of Ethics), a letter was sent from the new engineer to the original one. And a reply acknowledging their conversation and cooperation was reciprocated. The two professional engineers supported each other and helped to strengthen the profession by openly communicating on a matter which could have easily been overlooked or dismissed because of the passage of time.

Resolving a problem by seeking dialogue with another professional is the preferred step rather than invoking a formal complaint process with the regulatory body. Investigation and discipline committees would not be needed if there was dialogue, disclosure and mutual understanding arrived at by both sides. However, the world is not a perfect place and sometimes differences between parties result in formal allegations with investigations, charges and disciplinary orders.

\section{INVESTIGATION AND DISCIPLINE}

A common misconception of the public about the investigation and discipline process is that it is a way to get restitution from the engineer. This is not the case.

The investigation and discipline committees are one way in which the provincial regulatory associations protect the public.

The scope of the association's power is limited to the engineer's relationship (registration) with the provincial association in which they are practicing. In disciplinary cases, the association can take away an engineer's licence, limit the scope of their practice, require courses, require testing, and issue fines [10].

The purpose of the investigation committee is to gather evidence and determine if professional misconduct has occurred. While the purpose of the discipline committee is to judge the evidence collected, determine the guilt or innocence of the member involved and recommend appropriate punishment [10][11][12] [13].

\section{PROCESS}

Figure 1 outlines the investigation and discipline processes used in Manitoba. This process carries legal weight and parallels the standard legal pattern of complaint, investigation, trial, and appeal. Other Canadian jurisdictions vary in specific details but are consistent in the overall process and intent [12][14].

\subsection{Initial Processing}

When the initial complaint is received, it is evaluated by the regulatory body to ensure the individual being complained against is in fact a member of the profession. If they are, the complaint is forwarded to the investigation committee and the engineer is informed of the complaint. If they are not an engineer, than the complainant is informed that the person is not a registered engineer and a separate investigation into unlicensed practice may ensue.

\subsection{Investigation Committee}

The purpose of the investigation committee is to determine if there is enough evidence to substantiate a charge of professional misconduct. The process here is the committee meets and assesses the question: if the charges were true, would this constitute professional misconduct? If the charge would, then an investigation subcommittee is formed to investigate the matter and return with 
recommendations based on their findings.. If not, than the case is dismissed and plaintiff informed of the decision and given the option to appeal.

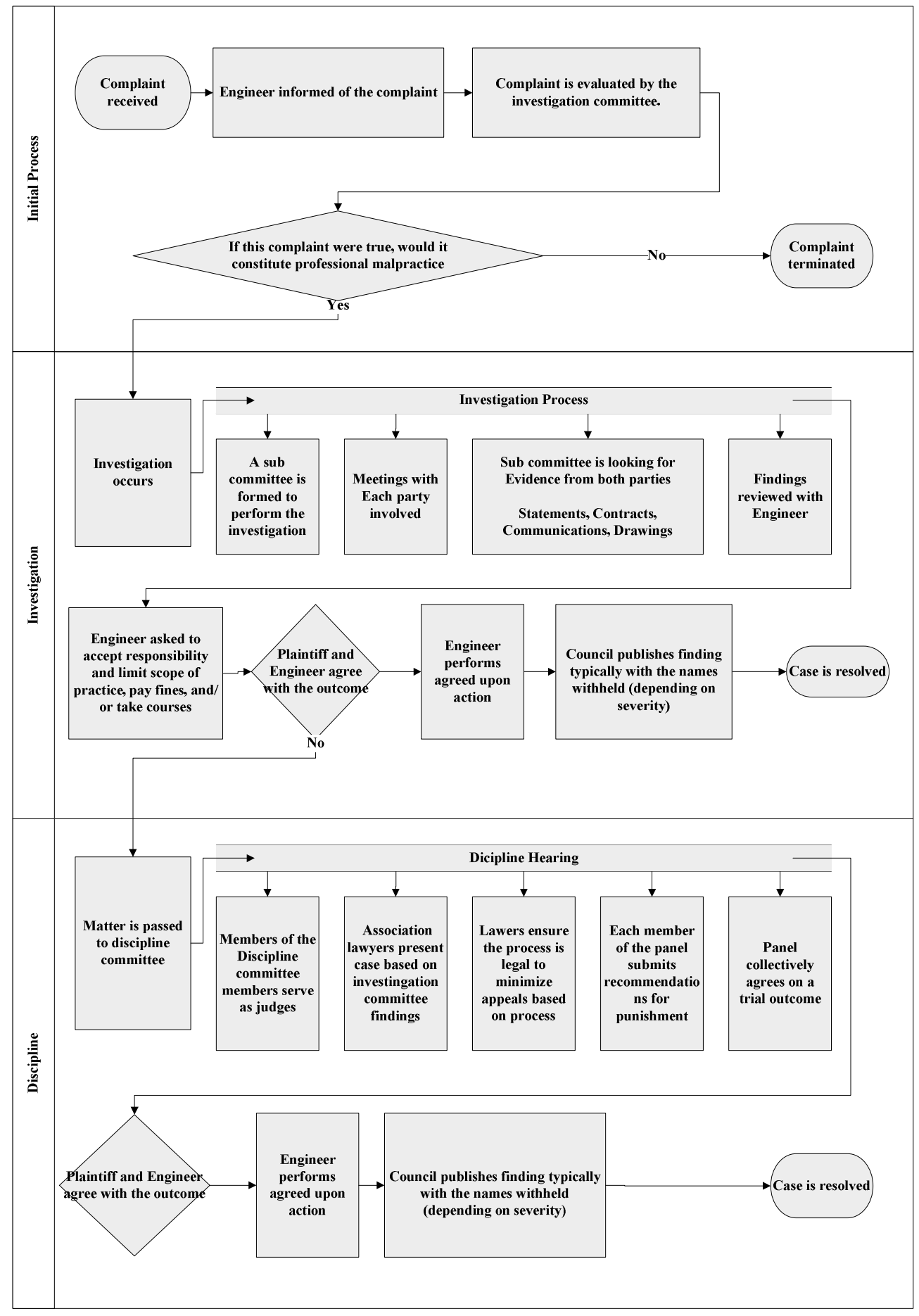

Figure 1: Engineers Geoscientists Manitoba Investigation and Discipline Process

CEEA17; Paper 027

University of Toronto; June 4- 7, 2017 


\subsection{Investigation}

During the investigation, both the complainant and the accused are given an opportunity to make their case and rebut the claims of the other. Additionally, the subcommittee will request documents supporting the engineers work, the contracts involved, and the communications with the client.

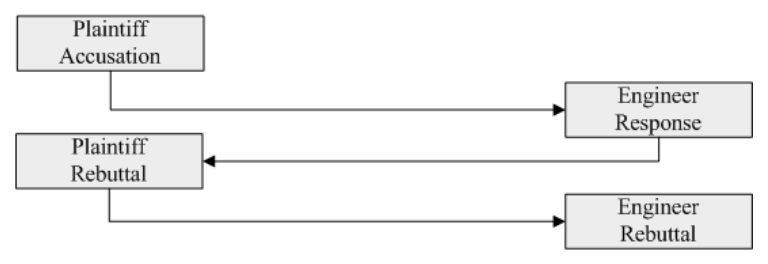

Sub Committee - Request for documents: Contracts, Building Plans, Communications

Figure 2: Investigation Process

When the subcommittee has finished their investigation, they return to the full committee with a report on the facts of the case and recommendations on discipline. At this point, the whole committee debates the matter and determines whether to dismiss the claim, forward their recommendations to the discipline committee, or investigate the matter further.

Once the matter is ready for the discipline committee, a member of the discipline committee reviews the recommendations for fairness, and the association informs the defendant of the findings. If the engineer agrees with the investigation committees findings and recommendations (essentially a plea bargain) they can end the matter. If the engineer accepts the settlement then the matter ends and the plaintiff is informed of the result.

If the engineer does not accept the findings and recommendations of the investigation committee, then the matter moves to trial before the discipline committee.

\subsection{Discipline Hearing}

At the discipline stage, a panel of three engineers from the discipline committee sit to hear the legal arguments of both sides. The panel is also advised on the legal processes as well, particularly, as to how they should behave, and what questions they can ask.

Interestingly, the stories told by both sides often take on new dimensions during the trial, as the parties recognize the seriousness of what is going on.

\subsection{Appeal}

In order to ensure fairness and consistency, appeals are possible at nearly every stage of the investigation and discipline process.

If the investigation committee rejects the claim of unprofessional conduct or technical expertise, then the plaintiff can appeal and try again.

If the engineer disagrees with the investigation committee's findings, then the matter is passed to the discipline committee.

If the engineer does not agree with findings punishment determined by the discipline committee, then they can appeal to council. To review the evidence and the severity of punishment imposed. At this point, a new committee is drawn from the association councillors who review the proceedings, and determine if the judgement was fair and consistent with prior findings.

If the engineer is still not satisfied, then they can appeal the matter to the Court of Queen's Bench who review the proceedings to ensure that proper legal procedures were followed.

\section{TEACHING ENGINEERING ETHICS}

In the experience of the authors, engineering ethics is taught in a two stage process in Canada. In University, ethics is a short module in a course combined with law and professional practice. Where ethics is learned, is in the workplace and during personal study for the Professional Practice Exam [13][15].

Looking at information about the professional practice exam[16][17] we see a strong reliance on multiple choice testing and thin case studies. The problem with thin cases is that they are often framed in an adversarial way, with little context as to the environment in which the situation is occurring and opportunities for resolution. As well, they typically focus on one engineer, one decision, one turning point. A situation that is unrealistic. Worse and the "emphasis on all-or-nothing dilemmas can be disabling for students" [18].

The problem with using big media, bad news [19] events like Elliot Lake and the Charbonneau Inquiry as case studies is that reinforces the message that engineering ethics is really about avoiding liability and the students look at these relatively unique events and think, that won't happen to me. I'm not going to be that guy. That's not the type of job I am going to be doing.

And they are right. For at least four years, they are not going to be practicing engineers; they are not going to be the ones taking professional responsibility for their work. At best they will be Engineering Interns or Engineers in Training under the supervision of a professional engineer who is responsible for their work. 
In order to connect with students it is important to ensure that they 1) perceive the information as personally relevant and valuable, 2) are active participants in the learning environment, and 3) feel confident that they can be successful even though this does not look like traditional, number based, single solution engineering problems.

\subsection{Personally Relevant and Valuable}

What will have more impact, is finding cases that are representative of the situations that EIT's might find themselves in. The cases highlighted in this paper were chosen because they are experience the members in training will likely be faced with, lying, professionalism, and reviewing the work of others. And although they will not immediately be the head engineer, they should be able to see how understand and demonstrate professional ethics upon graduation [20].

\subsection{Active Participants}

Case studies, CDIO, Inductive learning and experiential learning are all based on one underlying principle. When learners are active participants in knowledge creation, they learn more.

As [21] points out, a student's ethics don't change unless they have to interact with their peers and justify their positions. Professional ethics is about the actions you take, not how many cannons you can recite on an exam. It is about acting in a manner which generates trust in engineers and their work.

Drawing students in and making them active participants, hopefully it will help them understand that

\section{REFERENCES}

[1] "Wikipedia: Charbonneau Commission," 23102014. [Online].

Available: http://en.wikipedia.org/wiki/Charbonneau_Commissio n. [Accessed 1801 2015].

[2] "Montreal Gazette: Last day of public hearings at the Charbonneau Commission," Montreal Gazette, 1411 2014. [Online]. Available: http://montrealgazette.com/news/local-news/last-dayof-public-hearings-at-the-charbonneau-commission. [Accessed 1801 2015].

[3] "The Elliot Lake Inquiry," (Ontario) Ministry of the Attorney General , 10 2014. [Online]. Available: http://www.attorneygeneral.jus.gov.on.ca/inquiries/elli otlake/index.html. [Accessed 1801 2015]. they are not alone, and that unethical behaviour is the exception, not the norm.

\subsection{Feel Confident}

In conversation with students taking engineering ethics courses, they have revealed a great deal of frustration about not knowing how to succeed in the course. I find them asking, "What is the instructor looking for?" and "How can I answer these questions?". Unlike other science based engineering courses, ethics appears more subjective in its evaluation. Thus the students want to know how to structure and formulate their answers to meet the expectations of their instructor and obtain good grades.

\section{CONCLUSION}

Engineering Ethics is about generating trust by acting in a professional and accountable manner. And before an engineer enters the profession, they know or ought to know, how their technical expertise and professional behaviour will be evaluated.

To this end, this paper has presented three cases studies on professional practice aimed at engineering students and those registering to become engineers. The investigation and discipline process was broken down and explained so that a student could see the legal processes involved. And finally, recommendations were presented to encourage instructors to make discussions about ethics relevant, participatory, and fair in the minds of students.

[4] Association of Professional Engineers and Geoscientists of the Province of Manitoba (APEGM), "Code of Ethics for the Practice of Professional Engineering \& Professional Geoscience," Winnipeg, MB, 2000.

[5] Engineers Canada, "Good Character Guide," 2012. [Online]. Available: https://engineerscanada.ca/sites/default/files/guideline_ good_character.pdf. [Accessed 1 May 2017].

[6] Engineers Canada, "Frequently Asked Questions," [Online]. Available: https://engineerscanada.ca/frequently-asked-questions. [Accessed 1 May 2017].

[7] R. Hollander and C. R. Arenberg, "Ethics Education and Scientific and Engineer Research: What's Been Learned? What Should Be Done? Summary of a Workshop," The NATIONAL ACADEMIES PRESS, Washington, D.C., 2009. 
[8] Association of Consulting Engineering Companies Canada, "Contracts and Agreements," [Online]. Available:

http://www.acec.ca/business_resources/contracts_agree ments.html. [Accessed 1 MY 2017].

[9] Engineers Canada, "Guidelines catalogue," [Online]. Available: https://engineerscanada.ca/regulatoryexcellence/guidelines-catalogue. [Accessed 1 May 2017].

[10] Association of Professional Engineers and Geoscientists of BC, "Disciplinary Actions," 2015. [Online]. Available: https://www.apeg.bc.ca/ForMembers/Complaints/Disciplinary-Actions. [Accessed 10 March 2015].

[11] Professional Engineers Ontario, "Discipline," [Online]. Available:

http://www.peo.on.ca/index.php?ci_id=1823\&la_id=1. [Accessed 2 May 2017].

[12] Association of Professional Engineers and Geoscientists of Saskatchewan, "The APEGS Investigation and Discipline Process," 11 October 2013. [Online]. Available: http://www.apegs.ca/Portal/Sites-

Management/FileDownload/DataDownload/12453/AP EGS\%20Investigation\%20and\%20Discipline\%20Book let/pdf/1/1033. [Accessed 1 May 2017].

[13] Association of Professional Engineers and Geoscientists of Alberta, "Guideline for Ethical Practice," 02 2013. [Online]. Available: http://www.apega.ca/pdf/Guidelines/GuidelineEthical. pdf. [Accessed 1501 2015].

[14] Engineers Canada, "Canadian Framework for Licensure: Complaints and Investigations," 2 January 2013. [Online]. Available: http://www.engineerscanada.ca/sites/default/files/w_C onsultation_Complaints_Investigations.pdf. [Accessed 10 March 2015].
[15] Association of Professional Engineers and Geoscientists of British Columbia, "Code of Ethics Guidelines," [Online]. Available: https://www.apeg.bc.ca/getmedia/9356c6ab-15454949-9c22-52f2b5cbbffe/APEGBC-Code-of-EthicsGuidelines.pdf.aspx. [Accessed 1801 2015].

[16] D. W. Harder, "Professional Practice and Ethics: Case Studies," University of Waterloo, [Online]. Available: https://ece.uwaterloo.ca/ dwharder/PPE/Part_A_cases/ . [Accessed 1702 2015].

[17] G. C. Andrews and J. D. Kemper, Canadian Professional Engineering Practice and Ethics, Scarborough, Ontario: Nelson Thomson Learning, 1999.

[18] W. T. Lynch and R. Kline, "Engineering Practice and Engineering Ethics," Science, Technology \& Human Values, vol. 25, no. 2, pp. 195-225, 2000.

[19] C. Huff and W. Frey, "Moral Pedagoy and Practical Ethics," Science and Engineering Ethics, vol. 11, no. 3, pp. 389-408, 2005.

[20] Canadian Engineering Accreditation Board, "Accreditation Criteria and Procedures," Canadian Council of Professional Engineers, Ottawa, Canada, 2012.

[21] C. E. Harris, M. Davis, M. S. Pritchard and M. J. Rabins, "Engineering Ethics: What? Why? How? And When?," Journal of Engineering Education, vol. 85, no. 2, pp. 93-96, 1996. 